\title{
Notes on the Magnetism of Ships
}

\section{Frederick John Evans Master R.N., F.R.A.S.}

To cite this article: Frederick John Evans Master R.N., F.R.A.S. (1859) Notes on the Magnetism of Ships, Royal United Services Institution. Journal, 3:9, 91-110, DOI: 10.1080/03071845909422972

To link to this article: http://dx.doi.org/10.1080/03071845909422972

\section{曲 Published online: 25 Sep 2009.}

Submit your article to this journal $\pi$

Џلl Article views: 2

Q View related articles $\sqsubset$ 
Council. We have increased the Museum consilerably during the past year, by articles and specimens of a practical character, calculated to promote useful information among the younger members. Upon the part of the Council I will add, thit we shall endeavour to persevere in the course which we are now pursuing. We are gradually obtaining the good-will and countenance of the two Scrvices. Our progress canuot be rapid, for we have to overcome many difliculties; we have to show and to prove that there is an Institution in the country which is capable of collecting and conreying professional information. Gradually the officers of the Service are perceiving, that the more they become acquainted with all the details and with the science of their profession, the greater is the estimation in which they are held, and the higher pleasure will they take in all that belongs to it. This Institution is not yet what it will eventually become; but there are elements of success contained in its design, and when once a professional feeling is enlisted in its favour, which will, ere long, I anticipate, be the case, it will not fitil to become worthy of the Services and the Nation.

\section{NOTES ON THE MAGNETISAI OF SHIPS,}

Br Fuederick Jonn Evans, Master R.N., F.R.A.S., Superintendent of the Compass Department, Admiralty.

TuE object of the paper I propose to subnit to the Members of the United Service Institution this evening, is, to describe, in as brief and popular a manner as the subject will admit of, the progress and the present state of our knowledge of the magnetic condition of iron and wood built ships, and the consequent effect on the mariner's compass; together with the means at our disposal for analysing or detecting its clinracter, as also by offering suclı illustrations as may be worthy special remark, and, by recording the sources of my authority, to direct attention to the theoretical labours of the several eminent men of science who have contributed to this peculiar branch of knowledge so important to a maritime conmunity.

It is probably within the recollection of many of the Members of the Institution, that a lecture was given some seven years past in this theatre by the late venerable Dr. Scoresby, treating in part on tho same subject, and which then excited interest among many nautical men from the novelty of certain principles expounded, and to which I shall have occasion hereafter to revert.

The great increase of iron shipping since that time-short comparatively as it is -in our mercantile marine; and the colossal dimensions to which they have expanded; the further general introduction of huge steam engines, boilers, and shafts into our now gigantic frigates, and ships of the line, all tending to higlly develop the magnetic conditions of those fabrics, is of itself sufficient to invest the subject with interest, setting aside the fact that more than one disastrous shipwreck within the same period of time can be distinctly traced to unsuspected, or unallowed-for compass errors.

It may be interesting here to observe that the varying infuence of the 
iron of the ship on the mariner's compass had sorely baffled many of our early navigators, for we find Dampier, as recorded in his royage of 1691-3, complaining of being "puzzled" at certain anomalies in the amount of the variation of the compass, on passing the Cape of Good Hope, and which was doubtless due to local attraction.

Again, we find Mr. Wales, the astronomer who accompanied Cook our illustrious navigator in his second voyage of discovery, stating distinctly that "variations observed with the ship's head in different positions, and even in different parts of hor, will materially differ from one another; and much more will observations observed on board different ships."

In 1794, the first direct mention of the iron in the ship being the cause of disturbance, appears to have been made by Mr. Downie, the master of H.M.S. Glory, who in a report on a then newly-invented compass, observes that- "the quantity and vicinity of iron in most ships has an effect in attracting the needle; for it is found by experience that the needle will not always point in the same direction when placed in different parts of the ship; also, it is rarely found that two ships stecring the same course by their respective compasses will go exactly parallel to each other; yet these compasses, when compared on board the same ship, will agree exactly.

In 1801 Captain Flinders, of H.M.S. Investigator, found, by $n$ series of observations taken by the same compass in different parts of the ship, that a change of place from the binnacle to a little before the centre of the ship produced a difference of $41^{\circ}$ in the mean variation; and on his return to England in 1810, the Admiralty, in consequence of his representation, directed a series of experiments to be made at Sheerness on board several of H.M.'s ships: the resulting report contained some sound principles, but was based on too few observations and too limited conditions to be generally applicable.

Flinders dying soon afterwards, the subject received little attention till 1817, when Mr. Bain, a master in the royal navy, published a valuable little essay on the variation of the compass. Shortly after, in 1819, Professor Barlow engaged in an extensive course of experiments, with a view of discovering some principle of computation or correction for this source of error. After many investigations which will be found published, he proposed, by means of a circular disc of iron placed near the compass, to counteract the effect of the large masses of iron lying before and below the horizontal plane of the compass. This mode of correction was successful at the time, but on the application of so much wrought-iron in the structure of ships, particularly the machinery of steam-vessels, conditions arose which rendered the compensation by one plate of iron of a certain degree of hardness uncertain in its results; the correcting plate has therefore fallen entirely into disuse.

The introduction of iron-built vessels, some twelve to fourteen years after Professor Barlow's investigations, and the then existing doubts as to the possibility, or at least the security, of their navigation from the presumed powerfil magnetic action on the compass, gave increased interest to the subject; and we accordingly find that in 1835 the late Captain Edward Johnson of the Royal Navy, (the former Superintendent of its Compass Department,) undertook by direction of the Admiralty a scries of experiments in the iron ship Garryowen of 281 tons burden, lying in the river 
Shannon, with a view to ascertain the best position for the compass, as also the applicability of Barlow's plate.

It was then observel that the ressel acted as a permanent magnet on the compass and other magnetic instruments placed exterior to the vessel, and also that Barlow's plate failed as a corrector under the novel condition of its trial. Captain Johnson's paper and experiments in detail will be found among the Philosophical Transactions of the Royal Society for 1836 .

In $1838 \mathrm{Mr}$. G. 13. Airy, the present Astronomer Royal, also by the desire of the Bonrd of Admiralty, conducted a series of experiments on board the iron ressels Rainbow and Ironsides, with a view to discover the laws of magnetic disturbance These experiments further determined that the interior of an iron vessel acted upon the compass as a permanent magnet. 'The results, accompanied with elaborate investigations, are published in the Philosophical Transactions for 1839, and a popular account of the same experiments, and deductions therefrom, were afterwards given by Mr. Airy in the United Sertice Joumal for 1840, and also separately published by Mr. Weale of Holbom in the same year, with practical rules added for neutralizing the ship's disturbing force by the introduction of new and antagonistic disturbing forces in the shape of bar magnets and masses of soft iron.

Mr. Airy resumed the subject in later years, as additional records of observations in various parts of the world came under his notice, and a highly instructive (thougl in parts necessarily abstruse) paper was communicated to the Royal Society in 1855, and published in their Transactions for that year.

Preparatory to entering on the nature of and the laws affecting the magnetism of ships, it may not be considered irrelevant to touch concisely on a few of the general features of 'I'errestrial Magnetism, and I the more readily invite your attention to it, as bearing directly on the subject under review, and also as being one of those branches of science that should be acquired, at least in its general principles, as a necessary part of nautical education. In support, I may quote from the writings of one of the greatest philosophers of our time (Sir John Herschel): "Among the great branches of science which the present generation has either seen to arise as of new creation, or to spring forward by a sudden and general impulse into a fresh and more luxuriant state of development, there is none more eminently practical in its bearings and application than that of Terrestrial Magnetism."

Magnetism has been happily described as one of those unseen existences which, like electricity and heat, is only known by its effects. The magnetic condition of our globe is manifested at its surface by the three elements known as the Variation, Dip, and Intensity. The two former terms are, however, scldom used in scientific discussions, having given way to the modern appellations of Magnetic Declination and Inclination. The original and more simple names, which are familiar to every sailor, I propose to retain in this paper.

We may define the magnetic Variation as the amount by which the pointing of the compass-needle differs from the true geographical north; the magnetic Dip as the line of inclination to the horizon of a freely sus- 
pended needle, not limited in motion only to the horizontal plane, as is the compass-needle; the Intensity as the amount of magnetic force acting on the freely suspended needle, and giving it its direction. This latter element may be resolved into two components, one acting on the horizontal, the other in the vertical direction.

The Variation is in most parts of the globe undergoing continulal change, partaling of an annual as well as a diurnal variation. The latter follows a general law in either hemisphere: in the northern, the movements of the north pole of the needle from about 8 A.Jr. to 1 r.M is from east to west, it then becomes stationary, and with a slow motion retrogades to the east, arriving at the original point about 10 r.s., a smaller oscillation being observed during the night; the movement in the sonthern hemisphere is reversed in direction. 'The amount in angular value raries in different latitudes, and according to the sensons; in northern Europe it attains $15^{\prime}$ or $17^{\prime}$.

The annual change varies in different regions; at the present time (1859) in Great Britain the average decrease is about $6^{\prime}$. On the eastern coasts of Americi, nearly in the same parallel, it appears to be increasing by a similar amount.

I may take this opportunity of submitting for your examination a Variation Chart of the World,* which has engaged my attention for several months, and which has just been published by the Admiralty. It results from numerous observations made by the officers of H. MI. mavy, chiefly between 1850 and 1858, also from various magnetic surveys undertaken by the British and Foreign Governments.

The dip of the magnetic necdle engages but little the attention of seamen, though it is familiar to them that the compass-needle does not retain its horizontality on great changes of latitude, excepting through the medium of adjusting-weights. As the dip is an important element in the consideration of the changes of the magnetic condition of all ressels, but especially of iron ships, a brief account of its nature and distribution is necessary. The term magnetic poles is generally applied to those positions on the surface of the earth where the horizontal force disappears, and a freely suspended needle becomes vertical; the same end of the needle pointing in opposite directions in either hemisphere. In like manner the term magnetic equator is applied to those places where the needle has no inclination or dip, but rests in an horizontal direction: this line of no dip is irregular, and of double flexure, cutting the geographical equator in four points, and inclined to it generally at an angle of $12^{\circ}$.

The dip increases gradually on either side of the magnetic equator, and the lines of equal amount are nearly parallel to it till within the vicinity of the magnetic poles. A ship sailing along one of the lines of equal dip, is said to remain in the same magnetic latitnde, and she changes her matgnetic latitude most rapidly when her course is at right angles to those lines. 'The dip, like the variation, is subjeet to secular change; the annual decrease in the British Islands, and over a great part of Europe, has nveraged, for several years past, about 3 ; in the South Atlantic Ocean it is increasing about $G^{\prime}$ annually.

* Presented to the Library of the United Service Institution. 
'The intensity, in a philosophic point of view, is the most interesting element of terrestial magnetism, as from its general investigation.fruitful results in respect to the theory are antigipated; and it is practically useful for the seaman to lnow that the maguetism of his ship may be proportionally affected accorling to the regions of greater or lesser intensity passed through.

An ordinary and simple method of determining the intensity, is by vibrating a freely suspended dipping needle, which is acted on by the magnetic force of the earth in a similar manner to that in which the pendulum is acted on by gravitation: the squares of the number of vibrations in a given time at various places give the ratio of the intensity at those places. By the application of a more refined and difticult method, the absolute values may be determined; these values may be defined as a series of numbers representing the ratio of intensity to a given unit for every point of the carth's surface, and are represented on a chart by lines of equal value (isodynamic lines), similar to the rarintion chart submitted for your inspection.

An investigation of the lines of equal intensity tends to these results, viz., of there being two foci, or points of maximum force, in either hemisphere. 'These foci are of unequal force: the greatest in the northern hemisphere is in North America, the weaker in the north of Siberia: the corresponding phenomena in the sonthern hemisphere are not determined with the same precision, but appenr to have the same general characteristics. As a general rule, the magnetic intensity is least near the equatorial portions of the globe, and greatest in the polar-the vicinity of St. IIelena appearing to have the smallest amount yet discovered.

Having thus noticed those elements of terrestrial magnetism uecessary for a correct appreciation of our subject, we may now enter on the consideration of the theory of the magnetism of ships:-The errors of the compass on board ships arise from two distinet sourees of magnetism; the one transient, induced in the soft iron of the vessel; the other permanent, originating in the rolled and hammerch iron (differing from the condition of soft iron) employed in the construction of the hull and machinery.

Induced. magnetisn is due (1st) to the magnetic action of the earth, whereby every particle of "soft iron" is converted into a magnet, whose direction is parallel to that of the dipping needle, and which magnetic power it loses on removal from that influence; and (2dly) when exposed to the influence of any magnetic body, which induced magnetism it loses when the influencing body is remored.*

By permanent magnetism is understood the property of attraction and repulsiou belonging to a nass of hard magnetized iron, whatever may be its position; thus differing from induced magnetism, which, as stated, (1st) only acts in the line of the dip. "Hard iron" does not under ordinary circumstances become magnetic by induction; but when mag-

* The action of the earth on the north end of the needle is exerted in the direction which is called the lice of force. This is the direction of the dipping needle, viz., towards the rugnetic North, but inclined to the horizon at an angle equal to the magnetic dip, at the place-in England about $68^{\circ}$ below the horizon. $A$ bar of soft iron held in the direc. tion of the line of force of the earth becomes instantly magnetic, 
netized it retains the magnetic power even after the influencing body is removed, thus also difiering from the induced magnetism of " soft iron," (2dly), which vanishes directly thę infuencing body is removed.

We have now to consider the action of induced and permanent magnetism separately on the compass-ncedle, and which can be illustrated practically by using iron bars of either quality. Enploying a hard iron bas magnetized, and placing it in a direct line north or south of the compassneedle, with that end which attracts the north end of the needle being placed nearest the centre of the needle, it will be found to produce no deviation; when due east of the needle (as listurbed) it will cause a maximum easterly, and when west, a maximum westerly, deriation.

Note.-If we project the curve resulting from this experiment on the face of a compass-card, or from a straight line divided into 32 points, it will assume the form of figures 2 and $2 '$. (Plate I.)

The effect of a bar of soft iron on the compass-needle is more complicated, depending (1st) on the direction and amount of the dip at the place of observation; (2dly) on whether it is placed in a vertical or horizontal direction. In north magnetic latitudes, if placed in a vertical position, the upper end attracts and the lower end repels the north point of the needle; in south magnetic latitules the reverse occurs: on the magnetic cquator where the dipping-needle assumes a horizontal position, the vertical bar of soft iron will cense to be magnetic. The effect on the compass arising from this vertical portion of the earth's induction on soft iron is so far the same as that arising from the permanent magnetism of hard iron as to attract the north end of the needle as the ship swings round; but with a varying amount of attractive power proportional to the tangent of the dip, which latter magnetic element, as is generally familiar to seamen, rapidly alters in passing from north to south, or vice versat, over the globe; whereas the attractive force of the permanent magnetic bar varies in an inverse proportion to the horizontal magnetic intensity, and diminishes therefore for example between England and the Cape of Good Hope in the proportion of 20 to 16. This part of the deviation arising from the combined effects of permanently magnetic iron and of magnetism induced in soft iron by the vertical part of the earth's force, is termed by Mr. Airy "polarmagnet-deriation."

The nature of the change in the deviation produced by the permanent and induced magnetism respectively, on a change of magnetic latitude, is thus described by Mr. A. Smith, a high authority on magnetic science-

The first varies inversely as the horizontal force; the second varies as the tangent of the dip; their changes in different magnetic latitudes may be thus described : at a magne. tic pole of the earth when the dip is $90^{\circ}$, and the horizontal force zero, each part becomes infinite:-this indicates that there is then no directive force.

For some distance from the magnetic pole, the two parts change nearly at the sanie rate, and therefore the whole varies nearly as the tangent of the dip; but as we approach the magnetic equator, the part which arises from the soft iron diminishes the most rapidly. It becomes zero at the equator, and in south magnetic latitudes has the same value as in corresponding north magnetic latitudes, but the opposite sign. The part which arises from the hard iron does not become zero at the magnetic equator, but becomes a minimum at that line, nearly coincident with the magnetic equator, at which the horizontal force is a maximum, and in south magnetic latitudes it has the same sign and nearly the samo value as in northern. 


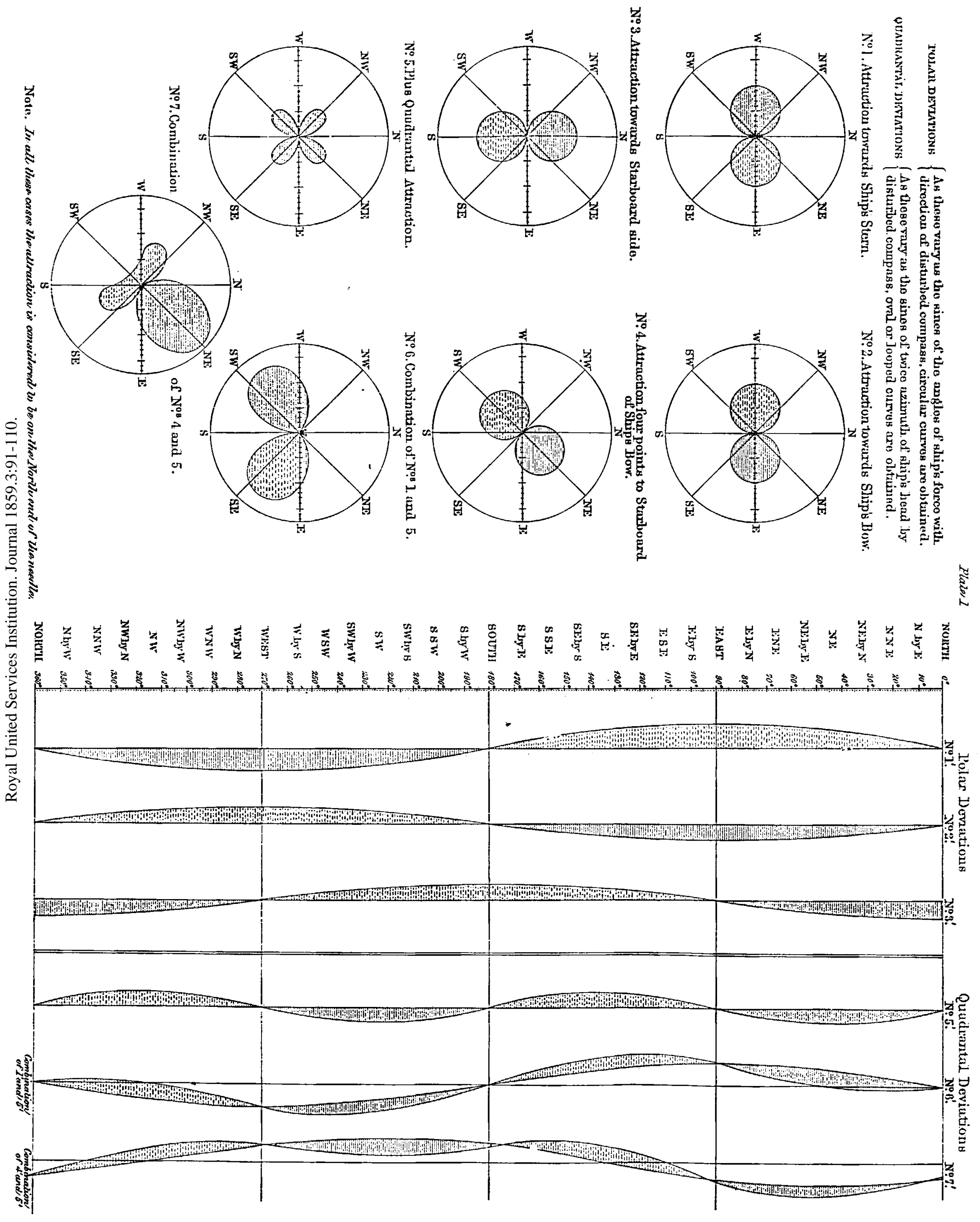


A horizontal bar of soft iron placed at the same level as the compassneedle, and in the sane fore and aft line, produces a deviation as the ship, swings round which has been temed by Mr. Airy "quidrautal," from clanging its character in each quadrant of the compass: thus, an easterly deviation oceurs when the ship's head is hetween north and east; westerly when between east and south; casterly deviation agnin between south and west, and resterly with the ship's head in the remaining quadrant: the maximum amounts of deviation being at N.E., S.E., S.W., and N.W., and the points of no deviation at north; south, east, and west. The reason of this action is readily explained: when the bar is at right angles to the magnetic meridian, or in a direction enst and west to the line of the beel when north and south, it censes to be magnetic; in any other position its south end attracts the north end of the needle and its north end repels it. But if the bar be placed in the line of the keel with the ship's head north and south, though it attracts the needle, it does so in the direction in which it points. and therefore produces no deviation: the chief action is therefore on the intermediate points.

Note.-By projecting the curve resulting from the experiment as just described, it will assume the form of fig. 5. Plate I.

It is especially worthy of note that the quadrantal deviation of the compass resulting from the combined action of the fore and aft horizontal portion of the soft iron in the ship is independent of locality, remaining the same in all magnetic latitudes.

Having laid before you the characteristic qualities of permanent and induced magnetism, it is now necessary to consider their combined action:if the magnetism of a ship iras due entirely te the action of "soft" iron and "hard" iron, it wonld be possible by observations made in any two magnetic lalitudes to determine the values of their parts separately; or theoretically from observations in the one geographic position to deduce the values in any other, as their laws of cliange have been fully investigated. But it will readily be conceired that a large portion of the iron entering into the composition of a vessel must vary in its nature between the extremes of " hard" and "sof." The magnetisn of this iron in an intermediate state has been named "subpermanent," or "retentive;" and it is from the combination of the permanent and induced being apparently so inextricably mixed up that to determine the value of the two portions separately by theory appears impossible. Other features also present themselves, for it is considered that the conditions of sulpermanent magnetic iron are liable to change from blows or straining of the vessel; and General Sabine has pointed out in his raluable contributions to Terrestrial Mragnetism, No. IX., (sce Philosophical Transactions for 1849, that the changes of magnetism corresponding to changes of the ship's place are gradual wather than instantaneous, or in other words that this portion of the magnetism depends not only on the place where the ship is, but where she has been for some preceding days or wceks.

Bearing the foregoing laws and facts in view, it will be understood how the deviations of the compass vary in character in different vessels on changes of geographic position:-In wood-built vessels, and especially YOL. 111 . 
sailing-ships, where soft iron predominates, the changes are due to induced magnetisn; lence the deviations diminish as the magnetic equator is approached, and change their direction on passing into at south magnetic latitude.

In iron-built vessels wliere permanent and subpermanent magnetism predominates, the changes of deviation are less regular, and the deviations may retain the same direction in both hemispheres. This is fully exemplified and borne out by examinations I have made of the numerous Tables of Deviations annually transmitted from II.N. ships.

For many years the Adniralty have published Practical Rules for ascertaining the deviation of the compass caused by the ship's iron, and which are doubtless familiar to most or indeed all naval officers. In 1851 the Hydrographic Office published the first, and in 1855 the second edition of a supplement to these practical rules. This useful and highly interesting little work (a portion of which I propose especially to bring to your notice) is supplied to H.M. Ships. The maritime profession is indebted to MIr. Archibald Smith, MI.A., F.R.S., of Lincoln's Inn, and late fellow of Trinity College, Canibridge, for this highly valuable contribution to navigation.

The part I wish to allude to, is an instructive process to analyse numerically the various portions of a ship's magnetisn due to the laws already explained, by which we are enabled to enter on an investigntion of, and generally to account for, any peculiarities in the deviations of the compass of particular ships.

$A$ devintion table having been formed by any of the processes now so generally understood, either on the thirty-two points of the compass, the sixteen intermediate, or the eight principal points - the values of five separate coefficients are deduced therefrom by the aid of mathematical formula, which latter have been much simplified in practice by neat tabular arrangements, appended blank forms, and with clear examples.

The five coefficients are distinguished by the letters $\Lambda, B, C, D, E$, and represent the values of the magnetic disturbance for each compass.

$D$ and $\mathrm{E}$ are termed the "permanent coeflicients," as they are presumed to preserve their values unchanged in all parts of the flobe.

$\mathrm{B}$ and $\mathbf{C}$ are coefficients which change on a change of geographic position, especially of latitude, and it is considered in a way generally impossible to be predicted, and as also to change from extraneous causes.

It is important to describe these coefficients in detail:- The coefficient $A$ is a constant error, it includes any correction which may be due to index crror of the standard compass, or the shore compass employed in observing the deviations, or to-a not unfrequent cause of error-the lubber-line of the former not being exactly fore and aft: whatever portion is due to magnetism arises from a peculiar non-symmetrical arrangement of soft iron in the immediate vicinity of the compass only likely to occur in small ressels. This coefficient is in general small: + sign denotes the easterly deviation is in excess; - sign the westerly in excess.

$D$ and $E$ are due to the "quadrantal" effects of the horizontal parts of the soft iron:- the valnes of $D$ are from that portion acting in the fore and aft or athwartship lines; + sign is due to masses before or abaft the com- 
pass; - sign to masses on starboard or port side:-the values of $E$ are from masses of soft iron in the intermediate angles.

$D$ has in general a positive value, and is large in amount, varying from $2^{\circ}$ to $5^{\circ}$ in most iron vessels. $E$ is in general very small.

$B$ and $c$, the changing, and generally the largest cocflicients, are due to the combined effects of the permament magnetism of the hard iron, and that induced by the vertical part of the earth's force in the soft iron, of which the separate laws of change have been already described:- $B$ represents that part of the combined attraction acting in a fore and aft direction, + if before the compass, i.e. the north end of the needle is drawn towards the bow; - if abaft it, i.e. the north end attracted towards the stern. c that portion acting in an athwartship direction, + if north end of needle drawn to starboard, - if north end of needle drawn to port.

Not the lenst valuable part of a knowledge of the fre coefficients is, that a table of deviations can be constructed from them, by which, whatever original errors of observation may have existed on few or many points of determination, these errors are then divided over the whole thirty-tro points of the compass.

In illustration of the principles of a ship's magnetism, and the value of this numerical analysis in determining its character, the case of H.MI.S. Sanspareil, of 71 guns, is deserving attention: the funnel of this ship is on the quarter deck, and distant from the standard-compass in its usual position on the break of the poop only 19 feet 4 inches; consequently there must be a lively affinity between them. In the Sanspareil's early equipment the funnel was of copper, and the deviations were small in amount, not exceeding $6^{\circ}$. In 1856, an iron funnel was substituted, when the maximum deviation in England amounted to $24^{\circ}$.

In the royage to the Cape of Good IIope, Captain Key observed the deviations to alter considerably, and on arrival in port the ship was reswung, and the deviations found to hare decreased to a maximum of only $4^{\circ}$.

'This was unquestionably a striking change, and in less careful hands might have been a source of much embarrassnent. In an interesting letter to the Hydrographer calliug attention to the subject, (which will be found in the Nautical Nragazine for October, 1857, ) Captain Key considers that the deviation of the needle is due only to the induced magnetism of the iron on board, and that its direction is regulated by the position of the poles of that iron.

By employing Mr. Smith's formulx, we are better enabled to judge of the general character of the magnetism of the Sanspareil, without risking any hypothetical opinions.

Computing the coefficients from the Samspareil's deriation tables observed in England and at the Cape of Good Hope, with the funnel down, (which brought it nearly on a level with the compass-ncedle,) we have the following results:-

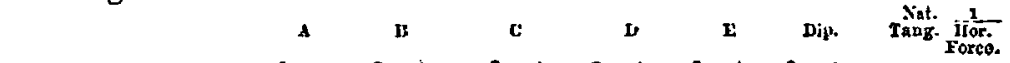

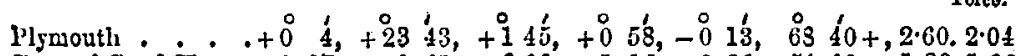
Cape of Good IIopo: $-037,+341,+208,+116,+0.36,5100-, 1 \cdot 38.1 \cdot 66$ Here it is obvious that the permanent coeflicients may be consideredII 2 
taking into account the probable small errors of observation-to hare stood the test of theory, and that the effect on the changing coefficients is duc to the combined action of permanent or polar-magnet deviation and induced magnetism. Were the deviations of the Sanspareil's compass due alone to the induced magnetism of the funnel and guns as surmised by Captain Key, the cofficient is would have differed from the am sunt in England $\left(+23^{\circ} 43^{\prime}\right)$ in the proportion of the tangent of the different dips, or as $2 \cdot 6$ to $-1 \cdot 4$, giviug a result of $-18^{\circ} 45^{\prime}$ instead of $+3^{\circ} 41^{\prime}$. Were they due to permanent maguetism alone, $\mathrm{B}$ would have differed from its amount in England in the proportion of 2.04 to 1.66 (values deduced from Gauss's chart of magnetic intensity) giving a result of $+18^{\circ} 58^{\prime}$ instead of $+3^{\circ}+1^{\prime}$. As the value of $\mathrm{B}$ deduced from the observation at the Cape, viz. $+3^{\circ} 41^{\prime}$, lies between the two values above deduced, we may infer that the polar-magnet deviation was caused in nearly equal proportions by the permanent or subpermanent maghetism and the induced magnetism.

The accompanying coefficients of two wooden sailing ressels, and two iron steam-resscls, as computed from observations made in England and at the Cape of Good Hope, are instructive examples of the changes according to the theory advanced.

$$
\begin{aligned}
& \text { II.M.S. Herald (Surveying Ship). }
\end{aligned}
$$

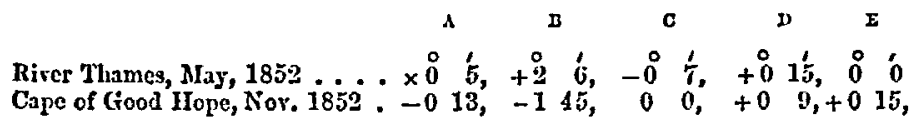

$$
\begin{aligned}
& \text { H.M.S. Mrander (40 guns). } \\
& \text { Sheerness, September, } 1852 \ldots-015,+110,+030,-015,+08 \\
& \text { Cape of Good llope, March, } 1853-023,-235,=03,-010,+06 \\
& \text { H.M.S. Simoom (Iron Troop Ship). } \\
& \text { Portsmouth, Scptembcr, } 1852 \ldots-07,+200 \pi,-713,+433,-019 \\
& \text { Cape of Good IIope, Oct. - } 1853-147,+1306,-223,+413,+022 \\
& \text { H.M.S. Vulcan (Iron troop Ship). } \\
& \text { Portsmouth, July, } 1852 \ldots .-013,-84 i,+043,+33 i,-041 \\
& \text { Cape of Good Ilope, Feb, 1853 . + } 8,-103,+119,+415,+051
\end{aligned}
$$

\section{On Deriation Curves.}

Graphic projections of the deviations of the standard compass are not only useful in practice, but serre as a simple and ready mode of obtaining a table of probable deriations for every point of the compass from observations made on a few points only, and particularly for illustrating the nature of the ship's magnetism, whether polar-magnet, or quadrantal, or the two combined. The earliest in point of date will be found in the supplement to the Admiralty Practical Rules, and is due to Mr. R.J. Napier of Glasgow; tae second by Captain A. P. Ryder, of the Royal Navy, is similar in principle, though simplified for scamen in a part of its application; and the third, designated the "straight line method," is due to 
Mr. A. Smith, F.R.S., and appended to the Board of Trade instruction for correcting the deviations of the compass.

The chief object of Mr. Napier's method is to determine the amount of deviation for each of the 32 points of the compass, from observations made on a few detached points (without entering into the diffuse calculations otherwise necessary), by tracing a curre deviating more or less from a straight line, which may be considered as the margin of a compass-card, cut at the north point and straightened:and straight lines gives at once a clear idea of the amount and character of the disturbing effects of the ship's iron. The exact conversion of compass courses into correct magnetic courses, and rice versâ, follows as an invaluable part of the method.

Captain Ryder's plan has more particular application to the conrersion of courses, as, from mere inspection of the curves of devintion as drawn on lis projection, correct magnetic or standard-compass courses and bearings can be at once obtained, and with little possibility of error. Mr. A. Smith's straight-line method will also be found a simple and convenient plan for tabulating the results of the observations, and of maling the " course" corrections.

Captain Nolloth, of the Council of this Institution, has also exhibited before you and explained a Deviation Diagram; it is giren in the first volume of the Journal of the Institution, accompanied with these remarks: "It appears that by this method of graphical delinention a convenient means is afforded of cunparing various forms of deviation curves, and of considering then in connection with the circumstances of magnetic influence under which they respectively occur."

In the accompanying diagrams, Plate I. projected both on Captain Nolloth's circular plan, and a simple adaptation of MIr. Napier's method, you will readily distioguish the characteristics of polar-magnet deviation (i.e. permanent maǵnetism and vertical induction) and quadrantal deviation; but it must be recollected that practically these two are combined in every variety of mauner.

'The easterly deriations are denoted by hatched lines, the westerly deviations are denoted by dotted lines.

Fig. 1 and 1', represents polar deviation alone, where the attraction is towards the ship's stern.

Fir. 2 and 2 , polar deviation alone, where the attraction is towards the ship's bove.

Fig. 3 and 3 , polar deviation alone, where the attraction is townds the ship's starloard sitle.

Fig. 4, polar deviation alone, where the attraction is 4 points on starvoard bow.

Fig. 5 and 5 , quadrantal deviation $(+)$ giving easterly deviation in the N.E. and S.W., and westrrly deviation in the N.E. and S.TV. quarters. Fig. 6 and 7 and $C^{\prime}$ and $7^{\prime}$ are combinations of the polar and quadrantal; fig. 6 being 1 and 5 combined, fig. 7,4 and 5 combined. In these two latter diagrams on Napier's method only the quadrantal excess or deficiency has been tinted.

I have now to bring to your notice, and under review, the valuable 
labours, still in progress, of a Committec formed at Liverpool by various gentlemen connected with the vast shipping interests of that port, and working also under the auspices of the Board of Trade, to collect observations and make experiments on the condition and distribution of magnetism in iron-built ships, and the general system of compass correction and management.

Two or three disastrous shipwrecks, clearly traced to compass crrors, occurring about the time that the iron navy of Liverpool was rapidly expanding, gave rise to rarious conflicting opinions on the safety of their navigation, and particularly on the subject of compass-compensation by magnets; these questions were discussed in various periodicals, and also at the British Issociation for the Advanecment of Science, held at Iiverpool in 1854: hence arose the formation of the Liverpool Compass Committee.

The publication in 1857 of the First and Sccond Reports of that body to the Board of Trade, and presented to both Ilouses of Parliament by command of IHer Majesty, enables the observations relative to the theory of the magnetism of ships to be extended, not only in confirning what has been alrendy advaneed, but in giving some more general views of its charneter and distribution, particularly in iron-built vessels.

A striking feature in these lieports is, that the researches of the various authorities already quoted, and their exposition of the laws of magnetic action on ship-board, have received ample confirmation from the various observations collected and experiments undertaken by the Committee. In the opening page of the Second Report they obscrve, that it has been "proved, too, most decisirely, that the deviations of the compass on board iron ships, when properly ascertained, are not of that irregulair and erratic character which many cards of deviation might lead one to suppose, but that they accord most closely with the deductions of theory and cxperiment, as exemplified in the works of the Astronomer Royal and MIr. Archibald Smith." And again, at p. 24, in alluding to certain fluctuntions in the amount and direction of a ship's induced magnetism,-_" These fluctuations do not appear, however, to affect practically an authoritative statement which has already been supported by the Committec, and which, as it forms the key to the correction and calculation of compass deviations, cannot be too earnestly repeated; namely, that a ship's magnetism for any given place may be rery closely represented by a permanent polar magnetic force in combination with a quadrantal force, or one changing its deviation in each quadrant as a ship is swung round."

Anong the various philosophers who, during the present half century, -a period noted for the progress of theoretical and experimental researchhave grappled with the perplexing and it may be said uninviting science of magnetism, none more perseveringly worked for practical ends than the late Rev. Dr. Scoresby, and to him is due the enunciation of the notable facts, that the distribution of magnetisn in an iron ship depends on the direction of the keel and head while building with reference to the magnetic meridian; and that this original magnetism is subject to great changes after launching, and also from other extraneous causes. The following from among the results of his investigations, as bearing on the subject, are worthy of extract.-(Mfagnetical Investigations, by the Rev. Wy. Sconeser, D.D., vol. ii. 1852, pp. 330-343.) 

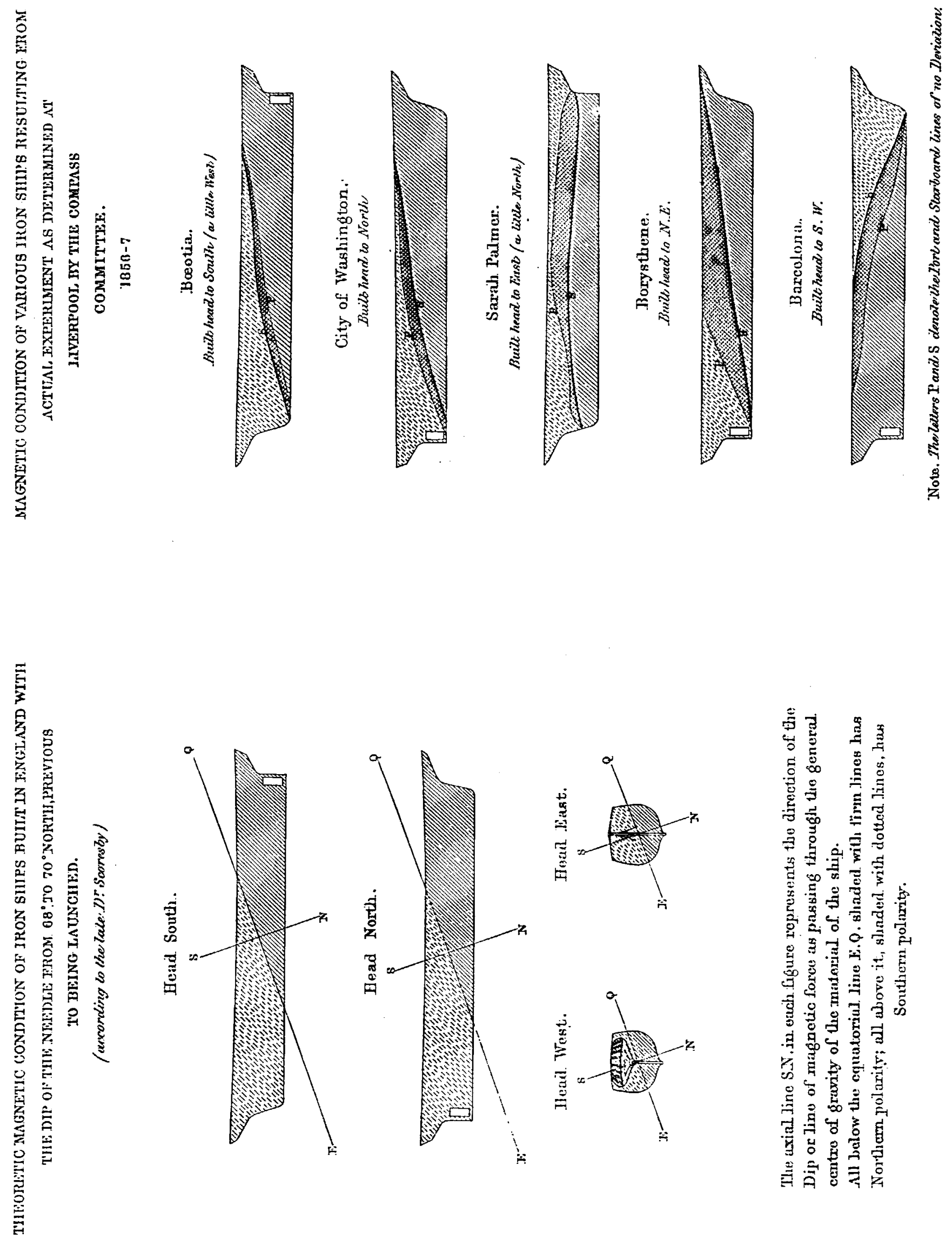
1. That ships built of iron, in place of timber and plank, ol,tain nccessarily $a n c x$ tchely high deguce of magnetic development from the claborate system of percussivo action, as well as from the bending of the plates and bars, during the progress of their construction.

2. That the dominant magnetism thus developed is of the retantice quelity, a quality remaining whilst terrestrially sustained by consistency of position, and otherwise, also, in relations inaceordant with terrestrial influence, whilst the ship remains free from mechanical violence or other magnetically disturbing force.

3. 'That in each iron ship there is a special individuality of the magnetic distribution, depending essentially on the position - characterised by the dircetion of the keel and head -whilst building, and peculienly on the deviations from uniformity in the placing of occasional heary masses of iron.

4. That, after being launched, percussion, vibration, or the straining of the general frame of iron-built ships, must $t \in$ end to equalise the relations of the ship's magnetisms with with those of the earth; and that the state of equalisation, or approximation thereto, will be hastened and adraneed, accordingly as the quantity or intensity of mechanieal violence is increased, and accordingly. as the ship's head is licpt pretty steadily in the same dircetion.

The accompanying diagrams (Plate II.) represcnt, according to $\mathrm{Dr}$. Scoresby, the theoretic magnetic condition of iron ships built in Englnnd, with the dip of the needle from $68^{\circ}$ to $70^{\circ} \mathrm{N}$., previous to being launched.

The confirmation of Dr. Scoresby's views will be seen from the following extract. "The records of the Committee no longer allow a doubt as to the connection which exists between the direction of a slip's original magnetism and her position when upon the building slip. In all the ships which have been examined, the north end of the compass-needle invariably deviated towards that part of the ship which was farthest from the north while she was building, if the compass was placed in a central position, and free from the influence of individual masses of iron."

The Reports also further proceed to show that the characteristic fentures of the original magnetism of an iron slip, by which is mennt the magnetism dependent on her direction when building, and the effect on a compass when she is swung, presuming that the necdle is not influenced by iron bulk-heads, or proximity to the stern-post, rudder-hend, or other masses of vertical iron controlliug the magnetism of the hull of the ship, is as follows:-

In an iron ship built with her head to the north, or nearly so, there is no apparent attraction of the needle towards either side while she lies in a north or south direction: but with her head in all other directions there is a strong attraction towards the stern.

With ships built head to the south, the same principle will apply, the deviation being then towards the bow.

When built with head to the cast, the deviation is towards the starboard side, (the south in building) and when built with the head to the west, to the port side, (the south in building): [this deviation must be considered as only due to a differential action, for if a compass be placed near the top sides of such ships either internally or externally, the north end of the needle (in north magnetic latitudes) is attracted; one side however attracts the needle more strongly than the other, and that is the side which was

* This is exemplified by the diagrams Plate 2. which represent the magnetic character of rarious ressels as determined by actual experiment at Liverpool while they were in lock. 
furthest from the north when the ship was building, as above stated.] In these ressels if placed in an east or west direction, the north end of the needle will tend to the bow or stern respectively according to the direction in which lies the greater mass of iron.

In ships built in intermediate positions the preceding characteristics are combined; thus, if built with head to the N.E., the attraction will be aft and to starboard; with the head to the N.W., aft and to port. If the head be S.E. or S.W., the attraction will be forward and to starboard, or forward and to port respectively.

The amount of original magnetism appears to have relation to the size of the ressel, or the quantity of iron used in her construction, and is thus illustrated:- "In a ship of 400 tons, built head to east, if a compass be carried fore and aft on the middle line, about three or four feet from the deck, the deriation may be $10^{\circ}$ or $12^{\circ}$ when her head is north or south. In a ship of 1,000 tons it may under the same conditions be $25^{\circ}$ or $30^{\circ}$, or more, depending to some extent on the breadth of the ship."

From a consideration of the foregoing illustrations, we may at once predicate the character of an iron ship's deviation from a knowledge of the direction of her kecl and head when building, or, vice versut, from having her devintion table we may infer the direction in which she was built: the accompanying table illustrates generally these conditions. 'Thus if

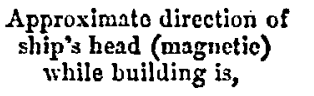

North.
N.E.
East.
S.E.
South.
S.IV.
West.
N.T.

\author{
Maxinum Easterly \\ deriation when ship's \\ head is near.
}

Maximum Westerly deria.
tion when ship's head is
near.

East.

S.E.

South.

S.TY.

West.

N.TV.

North.

N.E.

We have now arrived at an important feature of the inquiry-the alteration in the ship's magnetism after launching-and which would still appear to require an extended series of experiments to elicit more precise information. Numerous examples are given by the Committee, but derived more from information communicated than from direct experinent; still there is a notable example deduced from the latter in the case of the ship lioyal Charter, which will be hereafter alluded to. The conclusions arrived at are thus given:

This original nagnetism of an iron ship is frequently very permanent as regards direction, but is believed to undergo rapid changes in its anount, both in reality and in its apparent effect on the compass: the nost striking change being at and immediately after launching, and during the first royage. It is usually more evident in a steamer than in a sailing ressel. There are cases in which the de riations in a steamer have clanged so much as two points in the first two days at sea, while afterwards the change has not been more than $3^{\circ}$ in as many months. In new sailing ships the change is generally, but not always, more gradual, and estends over a longer period. A change of $10^{\circ}$ to $15^{\circ}$ is not infre. quent. 
A gain, Under sone circumstances considerably more than one half of a ship's original magnetism, or rather that part of it which affects the compass, may be lost, or may be. come balanced in the course of a year.

And, After this early reduction of a ship's magnetism has taken place, the remaining portion, as far as may be judged from examinations made in the sane place, and under the same circunstances, appears to be comparatively permanent.

In confirmation of this comparatively permanent condition of a ship's magnetism the Committe give a striking example in the case of the ship Great Britain; and it may be permitted me to express my opinion, having had the opportumity of inspecting deviation tables of nost of the iron vessels in M.M. navy, extending orer many ycars' observations, that from this evidence also their permanent condition appears to be the rule.

The Committee thus report on that well-known iron ship the "Great Britain:"-

This extraordinary ship has leen stranded, and strained, and altered; las traversed ioth hemisphercs, and been very many yars in active service : yet lier lines of no deviation are now much the same as Dr. Scoresby would indicate them to lisve been when she was upon the stocks. Yet how small is the change! a proof, apparently, that no circumstances can permanently conceul or greatly alter the direction of an iron ship's original magnetism.

[Illustrations in support of these views an given in the Committee Reports of the lines as taken in a graving dock, January, 1856; again in December, 1856, after being for some weeks head N.N.E. in the same graving dock: as they appeared two days after with her head in the opposite direction; and again as determined twice in January, 185̆7, after undergoing constant hammering in almost every part for forty-three days.]

The most instructive case of the rapid changes of magnetism in a newlybuilt iron ship is illustrated in the case of the ship lioyal Charter, whose leviations were carefully obtained prior to leaving England in January, 1856 ; at Melboume in Australia, in May, 1856 ; and again on her return to T.iverpool in August of the same year. These changes are well exemplified by a comparison of the values of the five coefficients alluded to; the results being selected from an extended series of observations, as made with an Admiralty standard-compass specially placed in aid of the cxperiments.

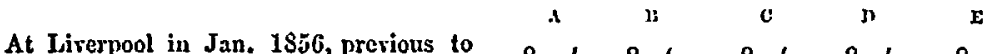

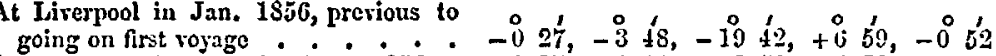

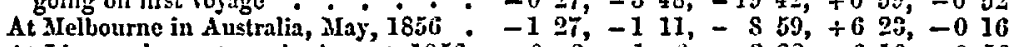
At Liverpool on return, in August, $1550-08,-16,-322,+610,+056$

We sce here very distinctly the permanency of the quadrantal deviation as represented principally by the cocflicient $D$; and the gradual diminution of the subpermanent magnetism, or polar-magnet deviation, in the coefficients $\mathrm{B}$ and $\mathrm{c}$.

Subsequent experiments in the loyal Charter indicate that the subpermanent magnetism is approximating to its original amount; but, as some alterations have been made in the ship's fitments, the comparisons are not strictly identical; they are nevertheless well worthy of attention.

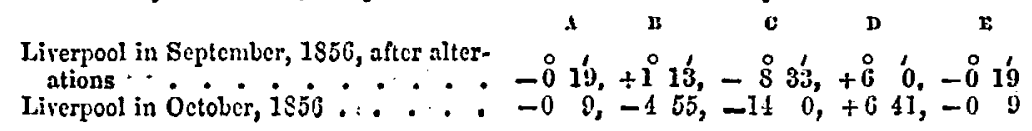


Enough has now been advanced to show the valuable nature of the investigations under review, but on the subject of the changes of original magnetism in newly-launched iron ships there appears to be ample scope for further inquiry, both as to the possibility of there being some regular law of change, as also as to the probable time required for the developement of its final permanency of charncter. The alarming change alluded to in the Reports by the Committec of "cnses in which the deviations in a steamer have clianged so much as two points in the first two days at sea, while afterwards the change has not been more than $3^{\circ}$ in as many months," is from its amount and irregularity sufficient to embarrass the most careful navigator; it is certainly to be hoped that the cases on which the statement is based are exceptional, and arising from the injudicious selection of a position for the compass (probably from close proximity to some ponderous mass, especially of vertical iron). I am certainly disposed to view them in this light from a consideration of the results obtained in the Royal Charter.

\section{On the Errors arising from the Hecling of Iron Ships.}

An important feature in the navigation of iron vessels, and one at the same time of a perplexing character to the navigator, are the clianges of deviation of the compass arising from the heeling of some ships.

In wood-built vessels the errors from this cause may be considered as in general too small in amount to be appreciable in practice, unless the compass is in close proximity to the guns or other masses of iron; but in iron-built vessels the results are not unfrequently of sufficient magnitude to call forth uncensing attention and vigilance. Our information on this liead is for the present very incomplete; but some few leading points can be traced, sufficient to place the seaman on his guard, and to draw attention to the general characteristics. Messrs. Rundell and Towson, the Secretary and Honorary Secretary to the Liverpool Committee, who have paid great attention to the subject, aud made various experiments, are of opinion that lieeling affects to the greatest extent ships that are built with their heads to the north or the south; and that the effect on the former is to draw the north end of the needle to the weathe: side, the deriations reaching their maxima when the ship's head is north or south (by compass), and having little or no effect when the ship's hend is east or west. In ships built with their head to the south, the north end of the needle will be drawn to the lee side, the maxima and minima deviations observing also the same conditions as those just described.

I propose now to enter somewhat briefly, as I have trespassed long on your attention, on the vexed question of mechanical adjustment for compasses.

Much controversy has taken place on the propriety and indeed safety of applying an antagonistic force to neutralize that of the disturbing effects of the iron in the ship: our highest magnetic authorities differ on the point, though agreeing in the main theoretical principles as to the nature of the magnetic disturbances. The Astronomer Royal is strongly in favour of correcting the deviation of the compass by opposing forces of magnets and soft iron. Admiral FitzRoy, Generil Sabine, and Mr. A. Smith, sup- 
portcd by numerous natical authorities, consider such corrections daugerous-except within certain limits, such as coasting navigation-and prefer a superior compass, to be considered a standard, fixed in an elevated position, convenient for careful bearings, as far remored as possible from the disturbing influence of iron, and using the binnacle compass merely as $n$ guide to the man at the wheel.

The opponents of the system of compensation urge that it is defective in principle and dangerous in practice; defective in principle so far, that it has not stood the test of experience in distant royages to the southern hemisphere, and dangerous inasmuch that it inspires the unskilled and unwary seaman with confidence in the stability of that which is not proved to be stable, and places in his hands a power over the action of the compassneedle, which he cannot control and of whose strength he is ignorant.

'The advocates, on the other hand, contend that a fertile source of error in navigation arises from the unslilful use of the deviation tables, the corrections being frequently allowed the wrong way, by which the original error is doubled; also that the tables do not provide for changes of the ship's magnetism caused by change of geographic position, or other circumstances; and again from the want of directive powrer of the needles under certain conditions of large devintion due to the ship's iron, combined with the earth's directive or horizontal force being small, as in the higher latitudes; which deficiency of directive power, magnet compensation would remedy.

There are just reasons in all or many of these arguments, and the question appears more to resolve itself, as my subsequent remarks will tend to shew, into one of application under varied but certain conditions.

In the Royal Navy, as recommended by a scientific committee of truly eminent men some years since, the system of no compensation is adopted as a general principle: but a rigid adherence to prescribed rules for preserving the compass as free from error as circumstances will permit is enforcedthus no iron is permitted within 14 feet of it, if practicable; and a careful selection of site fo: each compass in every ship is made under proper supervision. It is accordingly found to result that the amount of deviation in the lhoyal Navy is in general small comparatively, and that no example of a deviation larger in amount, even in our iron shins (in England) than from $25^{\circ}$ to $28^{\circ}$ exists, and this only in one or two exceptional cases.

The Mercantile Marine adopts more generally the system of adjustment, and this has led to the introduction of various patented compensating plans, differing widely from the Astronomer Royal's views, based often on no theory whatever, ending frequently in failure, and thus weakening the confidence of the seaman in the compass, and leading him to consider that the magnetism of an iron ship is so capricions as to be beyond all laws and all remedy.

These remarks may not be jnappropriately closed by referring to examples of the remarkable want of caution on the part of iron-ship constructors and those engaged in their equipment, evinced in the injudicious arrangements for the compasses given in the Liverpool Compass Committee's Reports. Among the instances quoted will be found the following, "The error in the first position of the binnacle was $101^{\circ}$. As the ship was going to the East Indies, the compass adjuster objected to compensate so large an 
amount, and the binmacle was then placed three feet forward; here the error was reduced to trro points. In another and much larger ship the compass in the first position of the bimacle deviated 14 points; on moving it a little further forward, the crror was reduced to $2 \frac{1}{2}$ points." These cases occurred when the original position was selected near the rudder-hend of iron vesscls, in which a strong attraction existed towarls the stern.

It must be evident that under such circumstances of position, no compass, whether compensated or otherwise, can possibly nct faithfully, nor can any accurate theoretical deductions be made from such examples; nor, abore all, need we be surprised at the serious consequences which too frequently result from dependence being placed on these marvellous malarrangements. The Liverpool Compass Committee acted wisely in the promulgation of a circular calling attention to these facts, and expressing their opinion that by attention to the circumstances under which $a$ ship is built, and care in selecting a suitable position for the binnacle, the original error of the compass may be reduced within small limits.

Any observations on the theory of a ship's magnetism would be incomplete without reference to Mr. Airy's method of compensating forces, based as it is entirely on the laws which have been referred to, that is,-

At any place the deriation of the composs in any ship, whether wood-built or ironbuilt, nasy be aceurately represented as the effect of the combination of two forces, of which one alone would produce a disturbance following the law of polar-magnet deviafion, and the other alone would produce a disturbance following the law of quadrantal deviation.

Conseruently, at any place the deviation of the compass may be accurately corrected by well-known mechanical methods; namely, by a magnet in the athwartship direction, fixed at a distance determined by trial, for correcting the deviation when the ship's head is north or south : by a magret in the head-and-stern direction, also at a distance determined by trial, for correcting the deriation when the ship's liend is east or west: and by a mass of unmagnetized iron, at the same level as the compasz, in the athwartship line or in the head-and-stern line, according to circumstances, (usually in the former,) also at a distance deternined by trial, for correcting the deviation when the ship's head is N.E., S.E., S.IT., or N.W.

For the same ship, the mass of unnagnetised iron, if adjusted at one port, will produce its due effect at all parts of the world, without ever requiring change or adjustment. The guadrantal deviation may thus be accurately corrected without difficulty, leaving only the polar.magnet deriation uncorrected.*

Mr. Airy's later investigations have led him to consider it desirable that the magnets should be mounted in such a manner that their distance from the compass can be delicately changed, to mect the changes of polar-magnet deviation.

We may expect at no distant perivd that there will be an accumulation of facts from various parts, particularly from the southern hemisphere, sufficient to prove the accuracy of Mr. Airy's views of compensation under all conditions, and whether its delicate and iniportant manipulations can

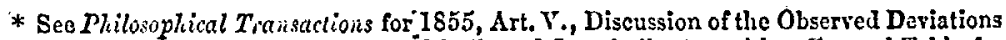
of the Compass in several Ships, Wood-built and Iron-built, \&c. with a General Table for facilitating the Examination of Compass Deviations, by G. B. Airy, Esq., Astronomer Royal. 
be entrusted to all classes of navigators. On one point however mariners many be assured, that at present no other method of compensation has been brought to their notice that has been more elaborately worked out by high scientific and philosophical attainments, or that could equally stand the test of such profound mathematical analysis as has been brought to bear on the subject by the Astronomer Royal.

Captain Nollotil, R.N.-I am sure we must all feel very much obliged indecd to Mr. Erans for his lucid, admirable, Lecture.

There is one observation which I will make, and in which I think you will agree with me, that too much importance cannot be attached to navigators frequently ascertaining the whole error of their compasses, from whaterer causes, by celestial observations during the voyage.

If I may hazard a remark concerning nomenclature, I would say that I do not see why we should use the term "devintion "as well as "variation," when the practical results are the same. I remember a man with whom I sailed as a passenger, and who-had navigated a ship for some time, allowing the deviation the wrong way, and, when I pointed it out, telling me that he never made a mistake in allowing for the rariation, but that lie was puzzled now and then with the other. It may appear strange that such a person should ever have been otherwise than puzzled; but there may be others equally troubled. When told that he might consider deviation merely a sccond rariation which had to be allowed for, the thing became clear to him.

MIr. Evans. - I think the term "deviation" is too firmly fixed to be rooted out, though it is a term of the present generntion only. The last generation had not iron ships.

Captas Col.unsox, R.N.-You have elucidated what I may call a somewhat hazy subject, and I have listened with great satisfaction to what you have said, because jou have pointed out many things which I was not acquainted with before. I wonld advise all narigators not to trust to any apparatus that is given them, but make positire observations. The mode of obtaining the raniation of the compass is so simple, that there is no reason, if the trouble is only taken, why any vessel should be misdirected in consequence of the attraction of the iron in the ship. We know when a vessel sails from a port, as she goes down the Channel in the first meridian altitude, the captain, if he only takes the bearing of the stm at the moment when it comes upon the meridian, and enters that in the log, has a standard by which he can then adjust his compasses. The same at. night with the stars. - When any object is on the meridin, you can get the error of the compass quite sufficient for all steering purposes. The unfortunate thing is this, that persons, after they have taken observations, do not record them. I would suggest that the captains, particularly of iron ships, when they go abroad, should be instructed to enter in the logs from time to time the errors, which they may get instantaneously by reference to the objects on the meridian; and in northern latitudes more especially by reference to the north star nt night. 
Min. Evans.-I may supplement the fow remarks youl have made by calling attention more particularly to these charts. It has been the practice to look upon this subject as a scientific matter, not within the comprehension of ordinary navigators. I do not think that such is the case. Take the case of the variation chart-its use is very great. Independent of its being a philosophical matter, a man having his position in any part of this chart, finding the variation by his compass, and comparing it with the variation, here at once gets his erros.

Crumsus.-On the part of the Council of this Institution, and those Gentlemen who have listened to Mr. Erans's exposition, I ber to tender hin our most sincere thanks for as interesting and valuable a paper as I think I have ever listened to in this Institution. I spenk upon this subject as an inexperienced man; but it appears to me that the more the matter is ventilated the better for the commercial marine, and it will probably be a great means of saving liuman life. 